\title{
EULOGY FOR THE LORD COOKE OF THORNDON
}

\section{Sian Elias*}

This eulogy was given at the funeral of Lord Cooke of Thorndon at St Paul's Cathedral, Wellington on 4 September 2006.

Lord Cooke of Thorndon was a great judge. The finest we have produced. He was also perhaps the best-known in the wider community. Through the work that came to him as a judge, he was involved in many of the major issues of the day. In law, he lifted our game. He made us proud to be New Zealand lawyers. He made us see that we have a legal system with its own values and traditions and he taught us to prize it. At the same time, he was a great judge of the common law and he kept us connected to the wider world of legal thought, which he himself did so much to develop. Although he achieved international stature, it was gained principally through his service as a judge in New Zealand for nearly 25 years.

In this cathedral, where he worshipped, we are in the part of Wellington where Robin Cooke grew up, married and worked. We come to express our sadness that he is no longer among us, to express our admiration and thanks for his life, and to say goodbye to him. Some have come a considerable distance. Many others would like to have been here. From London, Sydney, Hong Kong, Germany, Ottawa, Switzerland, the Hague and the Pacific (where he was generous of his time on appellate courts), warm messages have come in. There are many more in New Zealand, whose lives have been touched by Robin Cooke, who have not been able to get clear of commitments to travel to Wellington. Their thoughts turn this way.

The prodigious work that Robin did must have come at some considerable personal cost to those he loved. We all know of the public holidays worked and the nights when anyone passing up Molesworth Street could look into the corner office of the Court of Appeal and see a distinctive silhouette. In expressing our gratitude for his life of service to us, we also thank Annette, Philip, Christopher, Francis and their families - especially Annette - for their support through all the years. They have our very deep sympathy in this loss.

* Rt Hon Dame Sian Elias, Chief Justice of New Zealand. 
Robin Brunskill Cooke was born into a notable legal family, 80 years ago. His grandfather was the Crown Solicitor in Palmerston North. His father, a highly decorated soldier, had been the youngest QC ever appointed and became a respected Supreme Court Judge. He also had a mother who danced and a grandparent who painted. It was touch and go whether he would take up law or study English. In the University of New Zealand bursary exams which Robin Cooke took in 1942 in his $6^{\text {th }}$ form year at Wanganui Collegiate, he had the highest mark for New Zealand -504 out of a maximum of 600. The person in second place was Janet Frame, then at Waitaki Girls High School. The rest were way behind. When Robin won the travelling scholarship which took him to Cambridge in 1952, after he had obtained his LLB and LLM with first class honours from Victoria, his father suggested he might study English, but by then he had become hooked on law. English literature, however, remained a life-long passion and greatly enriched his own writing. The story is told that in court he once suggested to counsel a precedent could be found in Henry VI in Joan of Arc's recantation. Counsel regretted he was unfamiliar with the case. Lord Cooke never stopped reading Shakespeare. He kept paperback copies of the plays to tuck into his pockets to keep with him. He loved Dickens and Trollope. He did not care much for modern novels.

Robin Cooke was an outstanding legal scholar. Professor Williams at Victoria University College rated him the finest student he had taught. While a clerk at Chapman Tripp he hung around the courts, watching. All his life he believed that listening in court to real cases is one of the best forms of legal education, and regretted the fact that the exigencies of modern legal practice seemed to leave little time for such activity. He worked his passage to Cambridge in 1950 as a purser's assistant on the Rangitoto, something most of us will find difficult to imagine. His research supervisor in Cambridge was Professor ECS Wade. After two years at Clare College, he was made a Research Fellow of Professor Wade's College, Caius. At that time, administrative law did not even register as a title in Halsbury. The young Cooke was therefore in the vanguard of the intellectual movement that would later in 1982 lead Lord Diplock to say that creating a system of administrative law was the greatest achievement of the English courts in his judicial lifetime. (A claim for England that the Lord Cooke would later suggest was a little immodest considering the lead given by Canadian and New Zealand case law). Before returning to New Zealand, Robin Cooke was also admitted to the bar at Inner Temple, beginning a lifetime association with that Inn where he was later made an Honorary Bencher.

It must have been very tempting to stay in England, where doors were open to someone as gifted. His father's ill-health brought him back to New Zealand and to our benefit, he stayed. He married Annette. With some audacity and courage he went to the bar instead of going into a firm. In those days, when the junior bar was almost non-existent, it was unheard of to start off in that way.

Mr Justice Philip Cooke unfortunately did not live long enough to see what success his son achieved at the bar. Robin Cooke took silk at the unprecedentedly young age of 38 , slashing the previous record set by his father. It is difficult to know what influence the father had on the son. Although Lord Cooke has described his popular and dashing father as altogether the better man, my 
impression is that in legal thinking they were rather different. Certainly in one interview Lord Cooke indicated that the "principles" of the law were not much discussed at home. He said that it was from his father that he gained his affection for the personalities of the law, an enthusiasm he put to such good work in Portrait of a Profession, ${ }^{1}$ the centennial history of the New Zealand Law Society. In legal reasoning, the son seems to have found the father a little too cautious. He admitted reading his father's judgment in the 1955 Court of Appeal decision on the Bed of the Whanganui River with some surprise. He said it put him in mind of the "Mark Twain chestnut" that at 19 he realised how ignorant his father was, only to be amazed at the age of 24 to find out how much the old boy had learned in 5 years!

It seems safe to conclude that the approach the young Lord Cooke brought to his own work was shaped not by paternal conditioning but by the expansive experiences of Cambridge and by his own intellectual preferences. He may also have been influenced by the time, which was one of intellectual and artistic flowering in New Zealand. Robyn Hyde expressed the mood when she said about New Zealand: "We are hungry for the words that shall show us these islands and ourselves, that shall give us a home in thought." Law was a slow starter in this move towards emancipation from English influence. It was not until the 1960s that New Zealand judges started to shed what JL Robson and others have called essentially derivative thinking, hanging off the latest English cases. It was not until the 1970s that New Zealand judges started to strike out independently with any real assurance. The appointment of Mr Justice Cooke in 1972 was key to the development of a distinctive New Zealand jurisprudence from that time. When he moved to the Court of Appeal in 1976, a golden age in New Zealand legal history began. By the time he retired from the Court of Appeal, on receiving his peerage, he had served 20 years on the Court of Appeal, the last 10 as its President.

Everyone who knew Robin Cooke was struck by his beautiful mind. He was head and shoulders above most others in his intellectual capacity. He had the ability to make complex problems appear simple and to carry others with him by his clear and lucidly expressed exposition of legal principle. It would be wrong to give the impression, however, that he was isolated by this pre-eminence. $\mathrm{He}$ was not someone who paraded dazzling brilliance, unconnected with earlier thinking and leading nowhere. He was proud of New Zealand's legal history and traditions, about which he knew a great deal. He was not intellectually isolated. He was always current with academic thinking here and abroad. He started publishing articles in the Cambridge Law Journal and the Law Quarterly Review when still a research fellow. He kept on producing papers for publication all his life. His last piece was published in the Law Quarterly Review only a few months ago. He knew all the foremost legal thinkers. He was a friend to some of the great figures of law, including Lord Wilberforce, Lord Denning, Sir Anthony Mason and Professor Sir William Wade, all of whom he admired very much.

1 RB Cooke (ed) Portrait of a Profession (Reed, Wellington, 1969). 
He was generous to everyone, writing pieces for The New Zealand Law Journal, for University Law Reviews, launching books, opening chambers, visiting law faculties. There was nothing perfunctory about his contributions on such occasions. His remarks were always thoughtful, scholarly and fresh. They illuminated the law for us, and stimulated us to think. No other judge in my time played as active a role in the New Zealand legal profession, for which he continued to have great affection all his life. He admired New Zealand judicial work, including especially that of Sir Alfred North and Sir Thaddeus McCarthy, on whose judgments he frequently drew. He said that one of the happiest periods in his professional life was the time when he was junior judge in the Court of Appeal, with Justice Richmond as President and Justice Woodhouse as the next senior judge. The other period he mentioned was his "Indian summer" sitting as a Law Lord after his retirement as President of the Court of Appeal. Perhaps in the slot of junior judge he felt free to develop his ideas in a way that is more difficult for a presiding judge. Certainly, in later years, he referred very occasionally and obliquely to the anxieties of presiding: knowing when to compromise, when to defer and when to stand out. He regarded Goodwin (No 1$)^{2}$ as a "shambles." He later regretted not dissenting in one or two cases when he compromised for the sake of unity. On the other hand, he was proud of the unanimity in the first New Zealand Maori Council ${ }^{3}$ case, pointing out that the Court comprised five independently minded people "not necessarily usually of the same mind in issues touching the relationship of the legislative and administrative arms of government and the courts".

Robin Cooke knew a great deal of New Zealand legal history, as he demonstrated when writing the New Zealand Law Society centenary history, Portrait of a Profession. I am told that once he presided over a swearing in and recited the name of every judge since William Martin in 1842, to place the new judge in the tradition of the New Zealand courts and to remind him that he was part of it. On the occasion of the opening of chambers I belonged to in Auckland, he told us, without a note and in a lengthy and fascinating excursion around the topic, about every one of the 11 Chief Justices that had held office in New Zealand till that date. That sense of context, and the restraint of tradition it lays on individual judges, was I think key in his own judging. He was never flashy, never one to blow his own trumpet. He believed he was part of a great movement. He never left those of us who were a few steps behind feeling disparaged. He was patient in the explanation of his thinking, agreeing with another great Judge of the common law "in the end if you cannot explain your result in simple English there is probably something wrong with it."

Lord Cooke disliked labels, categories and other such impediments to the demonstration of legal principle in action. He was impatient of those who hankered after illusory certainty in law, pointing out that the untidiness of life did not allow things to be cut and dried. He was fond of quoting Lord Wilberforce's rejection of "the austerity of tabulated legalism." He preferred direct reasoning, to

$2 \quad R v$ Goodwin [1993] 2 NZLR 353 (CA).

3 New Zealand Maori Council v Attorney-General [1987] 1 NZLR 641 (CA). 
achieve realistic and common sense solutions which met human expectations. He believed in practical justice that delivered fair and reasonable outcomes. His knowledge of law was vast and gave him the assurance to restate and organise old principles for modern audiences. I discussed with him once the idea put forward by one of the Victorian judges that if you want to know the law you have to start with the Year Books and read through to the present. He thought the Year Books could be skipped as largely unintelligible, but expressed the view that there was no substitute for reading a great deal of law, as he had learned to do when researching his $\mathrm{PhD}$.

His impact on New Zealand law has been immense. There is no area of law that his judgments do not touch. This is not the occasion to attempt any proper review of his legal legacy. In his own lifetime he declined to name the cases he regarded as outstanding. He said that "the energies of the day and the biting of handkerchiefs [a reference to his rather distracting habit] are devoted to the case of the day. It is too early for a perspective." In the last few days, many judicial colleagues have mentioned their reliance on his judgments, always the first cited by counsel and in all areas of law: criminal, family, equity, negligence, and contract. It is the public law judgments for which he is principally known by the wider community. In them huge advances were made in natural justice, in judicial supervision of executive power, in human rights, in remedies, and in the insistence that questions of law are always ultimately for the courts.

It is not only in the substantive law that Lord Cooke has had such impact. In 1956, on his return from Cambridge, he criticised the New Zealand judiciary for its "unquestioning compliance" with English case law. He advocated closer examination of academic criticism and the case law of other jurisdictions, including the United States. From his time on the Court of Appeal there has been a revolution in legal method. It is hard to remember now how precious we were about citing the works of living authors, or United States materials, or non-legal publications. In 1977, sitting at first instance, he held that the Minister of Education had been wrong to discriminate between male and female married teachers for the purpose of a removal allowance. Although the blow for the equality of women was welcome indeed, the principal significance of the case today is that Mr Justice Cooke took into account the Universal Declaration of Human Rights and the Declaration on the Elimination of Discrimination against Women. It was a leap we in New Zealand now take for granted but which was breathtaking then. Lord Cooke was of the view that we are moving, slowly but inexorably, to a common law of the world, built on human rights. He regarded the Universal Declaration of Human Rights as "the most important document in legal history".

Contrary to folklore, Lord Cooke believed that it is not the role of the judge to mould society. "Other forces lie at the root of social change. In that regard, as in most others, the Judge has at best an identifying and balancing function." The importance of this function of identification and balance should not, however, be minimised. Lord Cooke said in an obituary for Lord Denning, but which I think applied also to his own approach to judging, that Lord Denning would not think of himself as a social engineer, one who altered people's lives. Rather, he was "one who laboured to ensure that they got better justice as they lived their lives." A great virtue of legal process in difficult cases, 
where society is unsettled, is its deliberation and impartiality. After the Maori Broadcasting case, brought to try to get Maori language on New Zealand television, two of the plaintiffs said to me after the Court of Appeal hearing: "Win or lose, we feel we have been heard at last". We lost - but we should not underestimate the human desire to confront issues that matter in formal process before a disinterested tribunal. Lord Cooke understood that need, and that the courts contribute to good government and nation-building by responding carefully and honestly to it.

The Treaty of Waitangi cases of course stand out. They were truly awful cases for all involved. So much was at stake. People who felt they had nothing to lose and no other option came to Molesworth Street to express their expectations of justice. The expectation of justice through law had been a theme at Waitangi in February 1840, in the great drama which started our nation off. In Portrait of a Profession Lord Cooke had expressed doubts about the Treaty's status. He said that while "attempts have sometimes been made to found legal arguments on the Treaty of Waitangi", "They may be taken to indicate that counsel has been driven to desperate straits."

Of course in the cases he had to decide, Parliament itself had imported the "principles of the Treaty" into the State Owned Enterprises Act, so the straits were not quite as desperate. The Treaty of Waitangi Act and the work of the Waitangi Tribunal had broken down a wall of ignorance. The Courts were a different matter. In the end, he himself was to come to say of the Treaty: "a nation cannot cast adrift from its own foundations". Reflecting on the first of the cases to come before the Court of Appeal, he has acknowledged that he was not readily led to the result. In the end, however, he said: "it would have seemed an abdication of judicial responsibility to decide otherwise." Lord Cooke was acutely conscious of the dangers for the court in cases such as these. He was of the view that "[t]here is not much point in accepting judicial office unless one tries to accept the unwelcome or disturbing, but crucially independent, responsibilities that go with it."

I never asked him, but it seemed to me that the breakthrough came when David Baragwanath, leading counsel in the case, read out to the Court the affidavit by Whina Cooper, in her own words, when she talked about the hills behind her home at Panguru on the Hokianga. I saw tears come to the eyes of the President.

I have not touched adequately on the great compassion of this man. His humanity, shown in many cases on many different topics, and underlying his deep commitment to human rights. His great courtesy to counsel. His interest in young lawyers, and the great encouragement he gave to so many of us, including women lawyers at a time when the profession was not entirely supportive. I have not mentioned how amusing he could be and his sly but never hurtful leg-pulling. I have not touched on other facets of his life like his love of cricket, and his mastery of crosswords. Many honours came deservedly to him: the Order of New Zealand; his honorary doctorates from Victoria University of Wellington and from Oxford and Cambridge (in a rare double feat); his knighthood; his peerage. 
Lord Cooke was entirely at home at Westminster in the House of Lords, in Cambridge or Oxford, at Inner Temple and in the members' pavilion at Lords. Though a supporter of abolition of appeals to the Privy Council, he was a monarchist, counting it a privilege to be one of Her Majesty's judges. He believed that in the rightful development of a New Zealand national identity "we need not throw away the privilege of a link to an ancient and much larger society as well". His contribution to New Zealand national identity was enhanced by his ability to live in both worlds. His life's work dominates the New Zealand Law Reports from 1972 to 1996. He also enjoyed sitting on the grass at the Basin Reserve or at Masterton or Palmerston North, following the fortunes of the Wellington cricket team. He enjoyed rugby. He might have been very good at golf if he had spared it the time. He loved his holiday home in Taupō and the landscapes around it, and he loved this city.

He was a great New Zealander and his pride in our country, its people, and its history is shown in his choice of arms on his elevation to the peerage. They depict two black robins above a shield divided by a cross, containing in the four quarters four volcanoes in silver, "inflamed": a reference to the explosion of Mt Ruapehu. The motto is Pro Aequitate Dicere - speak for fairness. The supporting figures are a mid- $19^{\text {th }}$ century captain of the Royal Navy (in evident reference to Captain Hobson) and a Maori warrior. These arms speak of Robin Cooke's love of the landscape of New Zealand, our foundation as a nation in the Treaty of Waitangi, and his life's work in speaking for fairness and justice.

We have had other great judges, and we will have more. I do not expect to see in my lifetime one such as this.

E te kaitautoko i te mana o te Ture

E te kaihapai e te mana o te Tiriti

E taku Ariki, haere haere haere

E kore koe e wareware. 
